\title{
Review of "Peer-Reviewed Publishing"
}

\author{
Hannes Almgren ${ }^{1}$ \\ 1 Ghent University \\ This is not a definition but a subjective opinion.
}

